\title{
Asymmetric Synthesis of Pyrrolizidines, Indolizidines and Quinolizidines via a Double Reductive Cyclisation Protocol
}

\author{
Stephen G. Davies*a \\ Ai M. Fletchera \\ Paul M. Roberts \\ James E. Thomson \\ a Department of Chemistry, Chemistry Research Laboratory, \\ University of Oxford, Mansfield Road, Oxford, OX1 3TA, UK. \\ steve.davies@chem.ox.ac.uk
}

Dedicated to Professor Victor Snieckus on the occasion of his $80^{\text {th }}$ birthday.

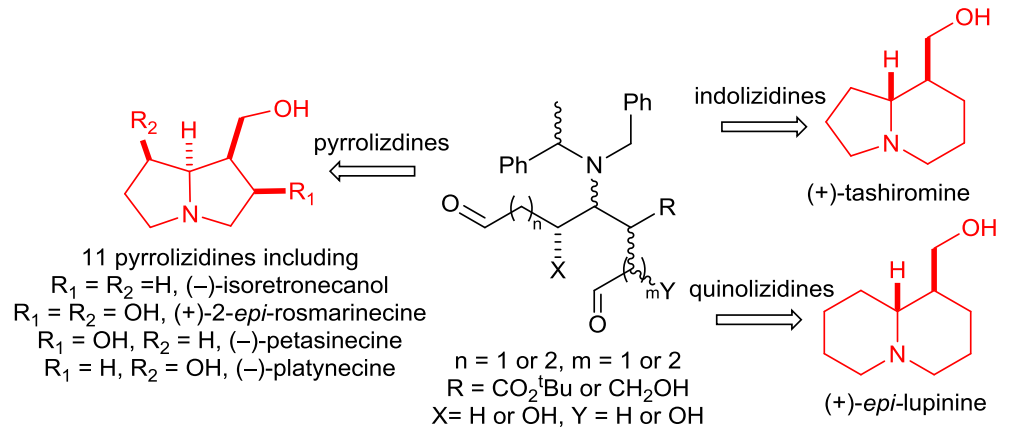

\begin{abstract}
Received: Published online:

Abstract This account describes an overview of the asymmetric syntheses of pyrrolizidines, indolizidines and quinolizidines via a common double reductive cyclisation protocol. The highly diastereoselective conjugate addition of an enantiopure lithium amide to an $\alpha, \beta$-unsaturated ester incorporating a terminal $\mathrm{C}=\mathrm{C}$ bond installed the nitrogen bearing stereogenic centre and was followed by alkenylation of the corresponding enolate to introduce the second olefinic functionality. Alternatively, conjugate addition to the corresponding $\alpha$-alkenyl $\alpha, \beta$-unsaturated ester followed by $\alpha$-pronation of the intermediate enolate may also be used to access the cyclisation precursor. After oxidation of the two terminal olefinic units to give the corresponding dialdehyde, tandem hydrogenolysis/hydrogenation was employed to efficiently construct the azabicylic core of each target molecule. This double reductive cyclisation strategy was successfully utilized in the syntheses of 13 azabicylic alkaloids or closely related analogues.
\end{abstract}

Key words Asymmetric synthesis, pyrrolizidine, indolizidine, quinolizidine, conjugate addition, lithium amide, reductive cyclisation

\section{Introduction}

Azabicycles with two fused aliphatic rings, whose endocyclic nitrogen atom is placed in a bridgehead position, can be classified depending on the ring sizes; pyrrolizidines 1 (i.e., [3.3.0]-azabicycles), indolizidines $\mathbf{2}$ (i.e., [3.4.0]-azabicycles) and quinolizidines 3 (i.e., [4.4.0]azabicycles) are the three most common classes. These structural motifs are commonly occurring within natural products, which display various biological activities. For example, (+)-pochonicine $\mathbf{4}^{1}$ exhibits GlcAc-ase inhibitory activity, (-)-steviamine $\mathbf{5}^{2}$ is known to display potent glycosidase inhibition, and (-)-swainsonine $6^{3}$ shows anti- $\alpha$ mannosidase activity. ${ }^{4}$ In 2003, (+)-epiquinamide 7 was first reported as an agonist for the acetylcholine receptor, thus has been of interest as a potential nicotinic receptor agonist (Figure 1). ${ }^{5}$

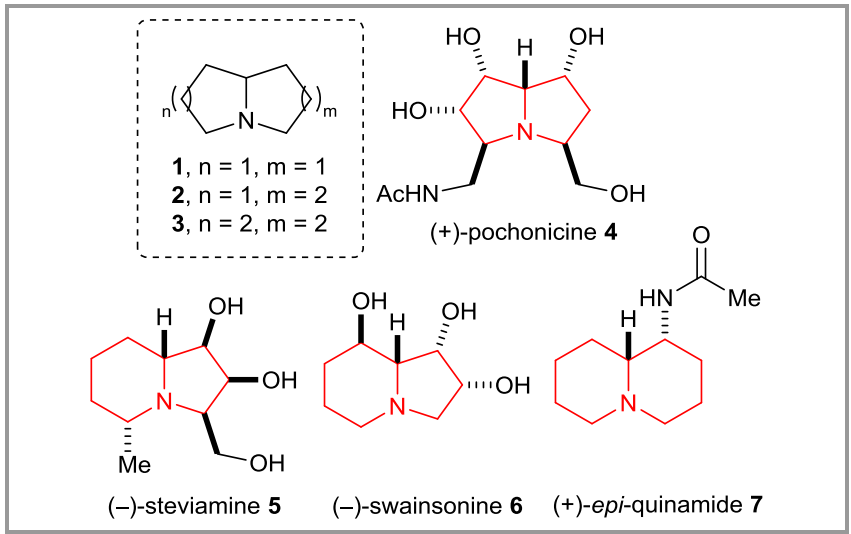

Figure 1 The core structures of pyrrolzidines 1 , indolizidines 2 and quinolizidines 3 , and selected biologically active azabicycles 4-7.

1-Hydroxymethyl substituted pyrrolizidines, indolizidines and quinolizidines are sub-classes of the corresponding azabicyclic compounds, several of which are known in Nature. For example, all four stereoisomers of 1hydroxymethylpyrrolizidines have been isolated from natural sources and named as (-)-trachelanthamidine 8, ${ }^{6}(+)$-laburnine ent-8, ${ }^{7}(-)$-isoretronecanol 9,8 and (+)-lindelofidine ent-9. ${ }^{9}$ Some plants containing 1-hydroxymethylpyrrolizidines are poisonous to livestock, ${ }^{10}$ and (-)-isoretronecanol 9 was reported to possess stimulant actions in the guinea-pig ileum preparation. ${ }^{11}$ Numerous analogous alkaloids of the 1hydroxymethylpyrrolizidines have been isolated and some of their biological activities have been evaluated: for example, (-)madhumidine A $\mathbf{1 0}$ displays weak cytotoxicity against cancer cell lines A549, PC-3 and MCF-7, and also inhibits NO production. ${ }^{12} 1$-Hydroxymethyl substituted azabicyclic natural products with other ring sizes (i.e., indolizidines or quinolizidines) have also been reported, for example (+)tashiromine $11,{ }^{13}(-)$-lupinine $\mathbf{1 2}^{14}$ and $(+)$-epi-lupinine 13 
display in vitro inhibitory activity against leukaemia. ${ }^{15}$ In addition, several polyhydroxylated 1-hydroxymethyl pyrrolizidines have been isolated from natural sources: ${ }^{16}$ for example, (-)-hastanecine 14, ${ }^{17}$ (-)-turneforcidine $15,{ }^{18}(-)$ platynecine 16, ${ }^{19}(-)$-petasinecine $17,,^{20}(-)$-macronecine $\mathbf{1 8}^{21}$ and (-)-rosmarinecine 19.22 However, limited data are known concerning their biological activity (Figure 2).

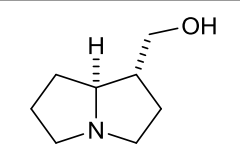

(-)-trachelanthamidine 8

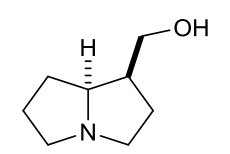

(-)-isoretronecanol 9

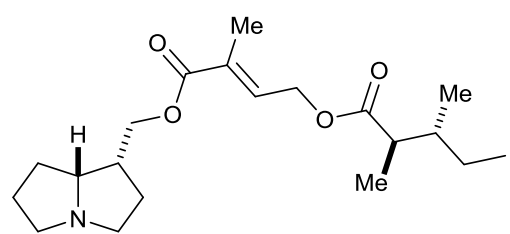

(-)-madhumidine A 10

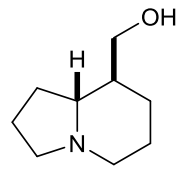

(+)-tashiromine 11

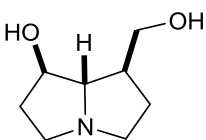

(-)-hastanecine 14

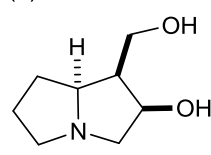

(-)-petasinecine 17

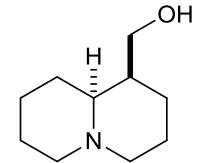

(-)-lupinine 12

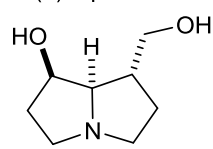

(-)-turneforcidine 15

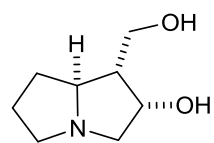

(-)-macronecine 18

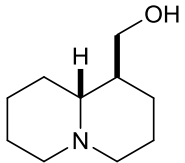

(+)-epi-lupinine 13

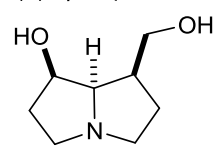

(-)-platynecine 16

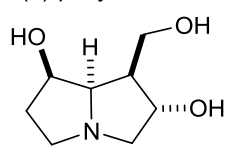

(-)-rosmarinecine 19
Figure 2 Naturally occurring 1-hydroxymethyl substituted pyrrolizidines, indolizidines and quinolizidines.

These classes of azabicyclic scaffolds have attracted considerable attention as synthetic targets in organic synthesis. The majority of the synthetic approaches involve stepwise formation of the two rings, ${ }^{23}$ although some have constructed both rings in one synthetic operation. ${ }^{24}$ We envisaged that the rapid construction of azabicyclic scaffolds, such as pyrrolizidines, indolizidines and quinolizidines, could be developed via a common double reductive cyclisation approach upon tandem hydrogenolysis/hydrogenation of a tertiary amino dialdehyde substrate such as $\mathbf{2 4 .} .^{25}$ The aldehyde functionalities could be revealed upon olefinic oxidation of the corresponding dienes $\mathbf{2 3}$, and these precursors can be prepared by diastereoselective lithium amide conjugate addition $^{26}$ of enantiopure lithim $N$-benzyl- $N$ - $(\alpha-$ methylbenzyl)amide $(R)-\mathbf{2 1}$ or $(S)$-21 to an $\alpha, \beta$-unsaturated ester 20, followed by enolate alkylation with an alkenyl halide 22. This account will describe a summary of our asymmetric syntheses of pyrrolizidines, indolizidines and quinolizidines using this double reductive cyclisation strategy as the key ringforming step (Figure 3).

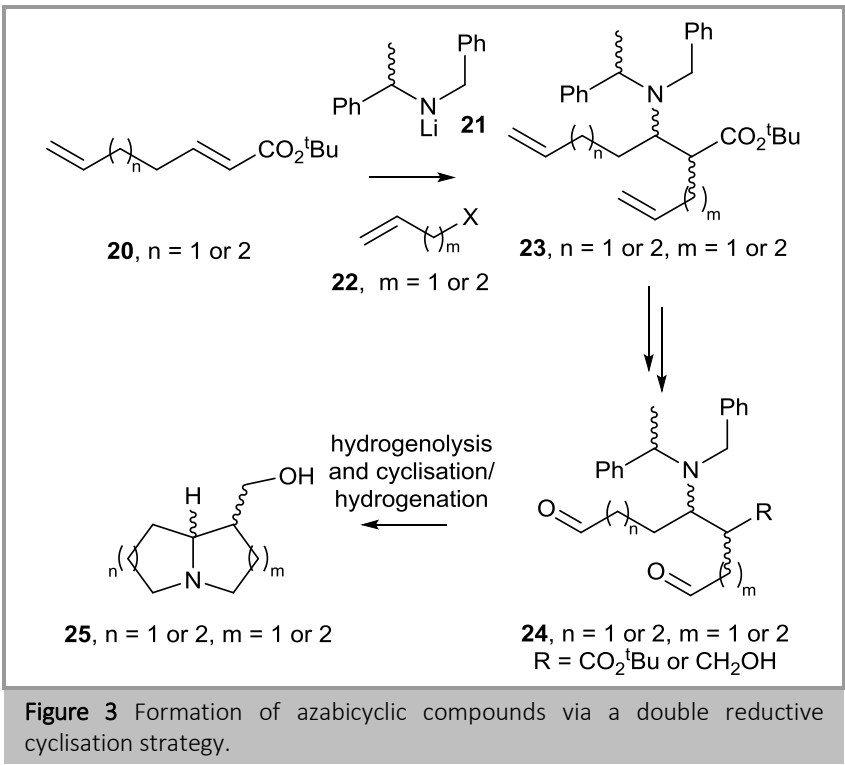

\section{Asymmetric syntheses of (-)-isoretronecanol and (-)-trachelanthamidine}

Our first endevours in this area culminated in methodology for the formation of pyrrolizidines via a double reductive cyclisation of the corresponding dialdehydes derived from tertbutyl 7-aminocyclohept-3-ene-1-carboxylates $\mathbf{2 8}$ and 29.27 The substrates were prepared via conjugate addition of $(S)$-21 to $\alpha, \beta$-unsaturated ester $\mathbf{2 6}$ followed by alkylation of the resultant lithium $(Z)$ - $\beta$-amino enolate ${ }^{28}$ with allyl bromide, which gave $\beta$-amino ester 27 in $60 \%$ yield and 85:15 dr. Diasteromerically pure $\mathbf{2 8}$ was subsequently isolated in $43 \%$ yield after ring-closing metathesis using Grubbs I catalyst. While epimerisation at the C(2)-position within 27 upon treatment with base was not possible, treatment of $\mathbf{2 8}$ (>99:1 dr) with $\mathrm{KO}^{\text {t} B u}$ gave $\mathrm{C}(1)$-epimer 29 in $80 \%$ yield and $>99: 1 \mathrm{dr}$. A superior overall yield of $\mathbf{2 9}$ was obtained without purification of the imtermeidate 28, after which $\mathbf{2 9}$ was isolated in $70 \%$ yield (from 27). Using our chemoselective epoxidation methodology, ${ }^{29}$ amine $\mathbf{2 9}$ was protonated first with $\mathrm{HBF}_{4}$ to protect the nitrogen lone pair from oxidation, followed by treatment with $m$-CPBA. Hydrogen bond directed epoxidation of $\mathbf{2 9}$ occurred on the same face as the ammonium group followed by in situ acid-mediated ringopening/lactonisation to give $\mathbf{3 0}$. Treatment of $\mathbf{3 0}$ with $\mathrm{LiAlH}_{4}$ gave triol 31 in $80 \%$ yield (from 29) and $>99: 1 \mathrm{dr}$. Oxidative cleavage of the diol unit within $\mathbf{3 1}$ with $\mathrm{NaIO}_{4}$ gave dialdehyde 32, and subsequent hydrogenolysis and in situ cyclisation/reduction, followed by purification on DOWEX ion exchange resin, gave (-)-isoretronecanol $9\left\{[\alpha]_{\mathrm{D}}{ }^{20}-70.5(c) 1.0\right.$ in EtOH) $\}$ in $65 \%$ yield and $>99: 1 \mathrm{dr}$. The epimeric cyclic $\beta$ amino ester $\mathbf{2 8}$ was reacted via the same sequence of reactions to give (-)-trachelanthamidine $8\left\{[\alpha]_{\mathrm{D}}^{20}-13.0(c 0.2\right.$ in EtOH $\left.)\right\}$ in $40 \%$ overall yield (from 28 ) and $>99: 1 \mathrm{dr}$ (Scheme 1). 


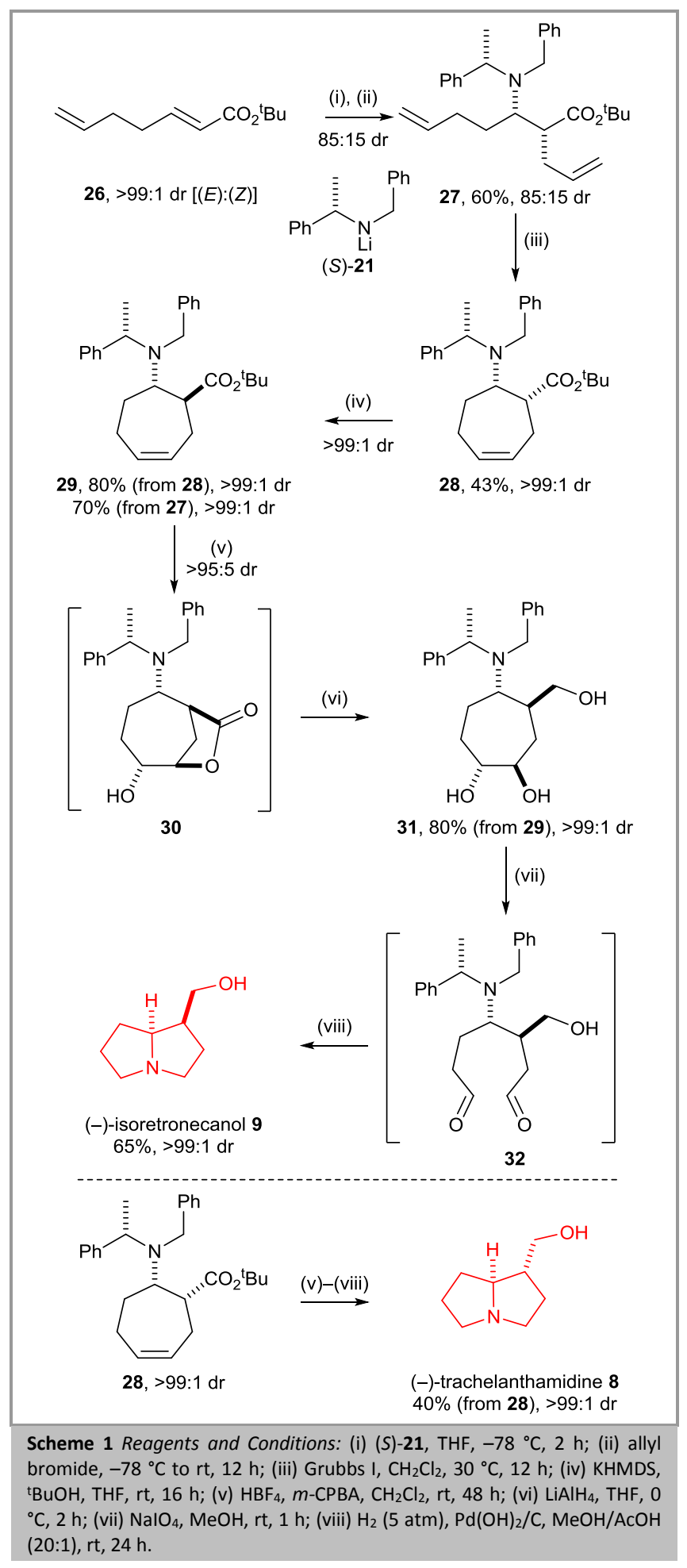

3. Asymmetric syntheses of (+)-trachelanthamidine [(+)-laburnine], (+)-tashiromine and (+)epilupinine

We have also applied the double reductive cyclisation protocol to homologous substrates to extend its scope to include indolizidines and quinolizidines. ${ }^{30}$ Conjugate addition of lithium amide $(R)-\mathbf{2 1}$ to $\alpha, \beta$-unsaturated ester $33(\mathrm{n}=2)$ followed by treatment of the resultant lithium $(Z)-\beta$-amino enolate $^{28}$ with allyl bromide gave a $65: 35$ mixture of $\mathrm{C}(2)$ epimers, from which the major diastereoisomer $\mathbf{3 4}$ was isolated diastereomerically pure ( $>99: 1 \mathrm{dr}$ ) in only $5 \%$ yield after exhaustive chromatographic purification. Analogous alkylation of the lithium $(Z)-\beta$-amino enolates resulting from conjugate addition of $(R)-\mathbf{2 1}$ to either $\mathbf{2 6}(\mathrm{n}=1)$ or $\mathbf{3 3}(\mathrm{n}=2)$ with but-3-enyl bromide failed. However, conjugate addition of lithium amide $(R)$-21 to $\alpha, \beta$-unsaturated ester $26(\mathrm{n}=1)$ followed by alkylation of the intermediate enolate with 1,4diiodobutane afforded a 60:40 partially separable mixture of $\mathrm{C}(2)$-epimers, from which $\mathbf{3 5}$ was isolated in $36 \%$ yield and $>99: 1 \mathrm{dr}$. Similarly, conjugate addition of lithium amide $(R)-\mathbf{2 1}$ to $33(\mathrm{n}=2)$ followed by alkylation with 1,4-diiodobutane gave a 63:37 mixture of $\mathrm{C}(2)$-epimers from which $\mathbf{3 6}$ was isolated in $18 \%$ yield and 89:11 dr. Chemoselective reduction of both 35 ( $\mathrm{n}=1,>99: 1 \mathrm{dr})$ and $36(\mathrm{n}=2,89: 11 \mathrm{dr})$ with DIBAL-H in PhMe gave alcohols 37 (>99:1 dr) and 38 (89:11 dr) in 72 and $86 \%$ yield, respectively. Subsequent treatment of $\mathbf{3 7}$ and $\mathbf{3 8}$ with $\mathrm{KO}^{\mathrm{t}} \mathrm{Bu}$ gave 39 in 56\% yield and $>99: 1 \mathrm{dr}$, and $\mathbf{4 1}$ in 33\% yield and 95:5 dr, respectively. In addition, $\alpha$-allyl- $\beta$-amino ester $34(>99: 1 \mathrm{dr})$ was reduced with $\mathrm{LiAlH}_{4}$ to give the corresponding alcohol $\mathbf{4 0}$ in 48\% yield and >99:1 dr (Scheme 2).

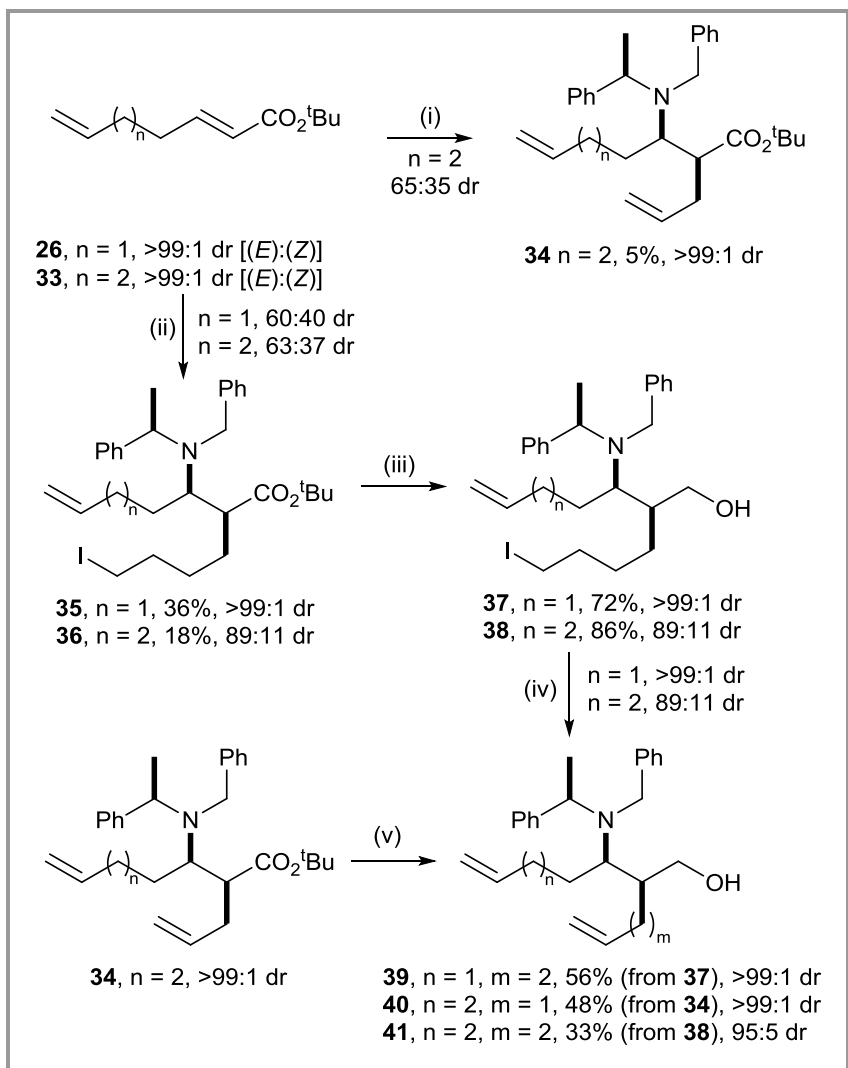

Scheme 2 Reagents and Conditions: (i) (R)-21, THF, $-78{ }^{\circ} \mathrm{C}, 2 \mathrm{~h}$ then allyl bromide, $-78{ }^{\circ} \mathrm{C}$ to $\mathrm{rt}, 12 \mathrm{~h}$; (ii) $(R)-21, \mathrm{THF},-78{ }^{\circ} \mathrm{C}, 2 \mathrm{~h}$ then $1,4-$ diiodobutane, $-78{ }^{\circ} \mathrm{C}$ to rt, $12 \mathrm{~h}$; (iii) DIBAL-H, PhMe, $0{ }^{\circ} \mathrm{C}, 4 \mathrm{~h}$; (iv) KOtBu, THF, rt, $16 \mathrm{~h}$; (v) $\mathrm{LiAlH}_{4}, \mathrm{THF},-78^{\circ} \mathrm{C}$ to rt, $18 \mathrm{~h}$

Unfortunately, cyclisation precursors 39-41 were obtained in low overall yields after exhaustive chromatographic purification, and ring-closing metathesis to give the corresponding 8- and 9-membered rings (in order to enrich the diastereoisomeric purity upon epimerisation) was not possible for these substrates. Therefore, an alternative, more selective, and higher yielding synthetic approach was investigated via diastereoselective conjugate addition of $(R)-\mathbf{2 1}$ to $\alpha$-alkenyl 
substituted $\alpha, \beta$-unsaturated esters 45-48, followed by diastereoselective protonation of the resultant enolates. Treatment of $\mathbf{4 2}$ with $\mathrm{NaH}$ followed by addition of either allyl bromide or but-3-enyl bromide gave $43(\mathrm{~m}=1)$ and $44(\mathrm{~m}=2)$ in 70 and $75 \%$ yield, respectively. Our modified WadsworthEmmons protocol ${ }^{31}$ was employed for olefination of either 4pentenal $(n=1)$ or 5 -hexenal $(n=2)$ upon treatment with either 43 or 44 and $M e M g B r$, which gave $\alpha$-alkenyl- $\alpha, \beta$ unsaturated esters 45-48 in good yield and moderately high $(E):(Z)$ ratios $(>70: 30 \mathrm{dr})$. Under the optimised conditions, ${ }^{32}$ the conjugate addition of $(R)-\mathbf{2 1}$ to $\mathbf{4 5 - 4 8}$ and subsequent addition of 2,6-di-tert-butyl phenol gave $\alpha$-alkenyl- $\beta$-amino esters ent-27, 49, $\mathbf{3 4}$ and $\mathbf{5 0}$ as single diastereoisomers (>99:1 dr) in $35-54 \%$ yield. Various attempts at the ozonolysis of these substrates (as the corresponding hydrochloride salts) were found to be problematic. However, dialdehydes 51-54 were obtained upon treatment of ent-27, 49, 34 and $\mathbf{5 0}$ with $\mathrm{OsO}_{4}$ and $\mathrm{NaIO}_{4}$ in the presence of 2,6-lutidine. ${ }^{33}$ The tandem hydrogenolytic $\mathrm{N}$-debenzylation/double reductive cyclisation of dialdehydes 51-54 was followed by reduction of the resultant azabicyclic esters with $\mathrm{LiAlH}_{4}$ to give the corresponding hydroxymethyl substituted azabicyclic targets. Purification of the crude reaction mixtures gave (+)trachelanthamidine $[(+)$-laburnine $]$ ent-8 $\left\{[\alpha]_{\mathrm{D}^{25}}+15.9(c 1.0\right.$ in EtOH)\}, (+)-tashiromine $11\left\{[\alpha]_{\mathrm{D}} 25+39.0(c \quad 0.2\right.$ in $\left.\mathrm{EtOH})\right\}$, $(1 S, 8 \mathrm{a} R)$-1-(hydroxymethyl)octahydroindolizine $\mathbf{5 5}\left\{[\alpha]_{\mathrm{D}}{ }^{25}\right.$ $+39.8(c 0.5$ in EtOH) $\}$ and ( + -epi-lupinine $13\left\{[\alpha]_{\mathrm{D}}{ }^{25}+29.1(c\right.$ 0.3 in $\mathrm{EtOH})\}$ as single diastereoisomers $(>99: 1 \mathrm{dr})$ in each case (Scheme 3).

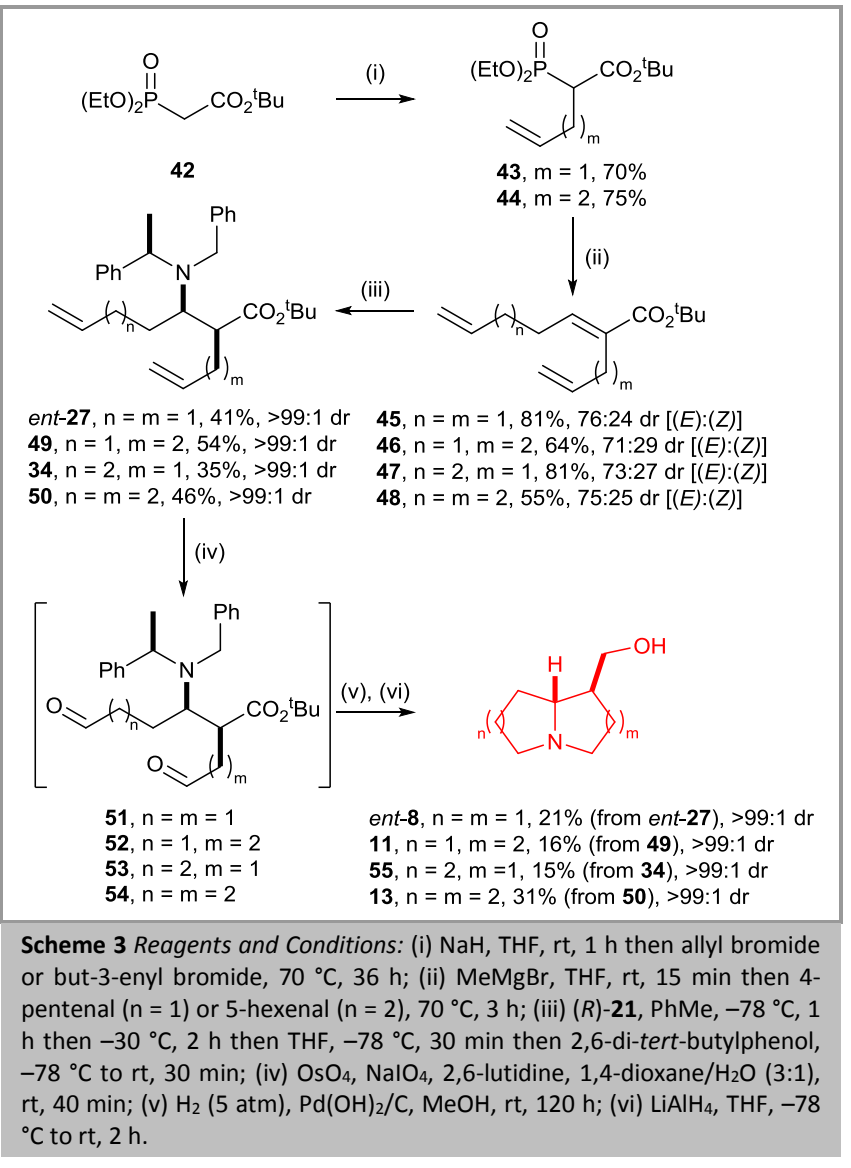

\section{Asymmetric syntheses of (-)-hastanecine,} (-)-turneforcidine and (-)-platynecine

Double reductive cyclisation was next employed in the synthesis of hydroxylated pyrrolizidines starting from enantiopure $(R)$-56 $\left(96: 4\right.$ er), ${ }^{34}$ which was prepared from commercially available 2,2-dimethoxyacetaldehyde using known enantioselective allylation conditions. ${ }^{35}$ Conjugate addition of $(R)$-21 to $\alpha, \beta$-unsaturated ester $(R)$-56 (96:4 er) gave 57 in 64\% yield and $>99: 1 \mathrm{dr}$, while conjugate addition of $(S)-\mathbf{2 1}$ to $(R)-\mathbf{5 6}(96: 4$ er) gave $\mathbf{5 8}$ in 71\% yield and $>99: 1 \mathrm{dr}$ after purification. In both cases, the reactions were completely diastereoselective under the (totally) dominant control of the lithium amide reagent. Treatment of $\beta$-amino ester $\mathbf{5 7}$ with TBAF promoted $O$-desilylation and in situ lactonisation to give exclusively $\mathbf{5 9}$ in 70\% yield and >99:1 dr. Treatment of lactone $\mathbf{5 9}$ with LDA and allyl bromide gave $\mathbf{6 0}$ (76:24 dr) initially and subsequent treatment of $\mathbf{6 0}$ (76:24 dr) with KOtBu gave $\mathbf{6 0}$ in $58 \%$ yield (from 59) as a single diastereoisomer. Identical treatment of $\beta$-amino ester $\mathbf{5 8}$ gave $\mathbf{6 1}$ in $42 \%$ yield (from $\mathbf{5 8}$ ) and >99:1 dr (Scheme 4).

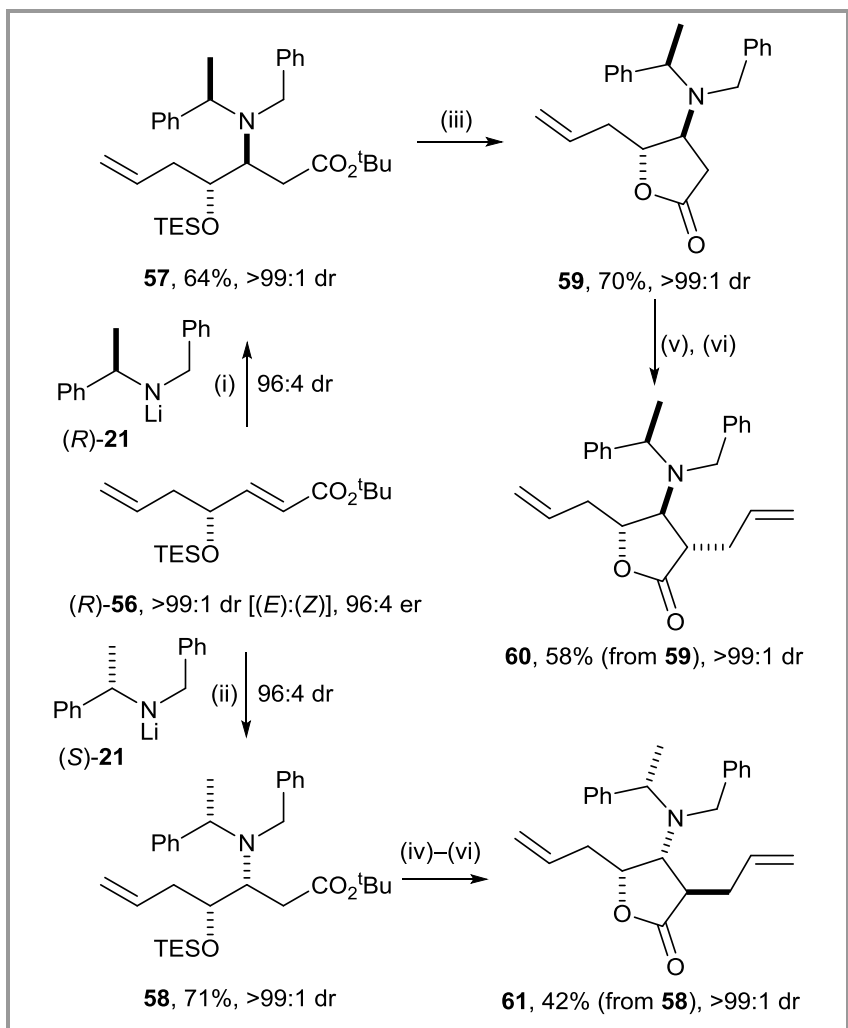

Scheme 4 Reagents and Conditions: (i) (R)-21, THF, $-78^{\circ} \mathrm{C}, 2 \mathrm{~h}$; (ii) (S)-21, THF, $-78{ }^{\circ} \mathrm{C}, 2 \mathrm{~h}$; (iii) TBAF, THF, rt, $16 \mathrm{~h}$; (iv) TBAF, THF, rt, $48 \mathrm{~h}$; (v) LDA, THF, $0{ }^{\circ} \mathrm{C}, 1 \mathrm{~h}$ then allyl bromide, $0{ }^{\circ} \mathrm{C}$ to rt, $2 \mathrm{~h}$; (vi) KO $\mathrm{K}^{\mathrm{Bu}}$, THF, rt, $18 \mathrm{~h}$.

Reduction of 60 with $\mathrm{LiAlH}_{4}$ gave diol 62 in $64 \%$ yield and $>99: 1 \mathrm{dr}$. Treatment of $\mathbf{6 2} \cdot \mathrm{HCl}$ with ozone followed by addition of polymer-bound $\mathrm{PPh}_{3}$ gave the corresponding dialdehyde 63, and subsequent hydrogenolytic removal of the $\mathrm{N}$-protecting groups facilitated in situ double reductive cyclisation. Purification of the crude reaction mixture on DOWEX ion exchange resin gave (-)-hastanecine $14\left\{[\alpha]_{\mathrm{D}}^{20}-8.3\right.$ (c 0.9 in EtOH) $\}$ in $82 \%$ yield (from $\mathbf{6 2}$ ) and $>99: 1 \mathrm{dr}$. Reaction of $\mathbf{6 1}$ via the same sequence of transformations gave (-)-turneforcidine 
$15\left\{[\alpha]_{\mathrm{D}}^{20}-10.0(c 0.8\right.$ in $\left.\mathrm{MeOH})\right\}$ in $34 \%$ yield (from 61) and $>99: 1 \mathrm{dr}$ (Scheme 5).

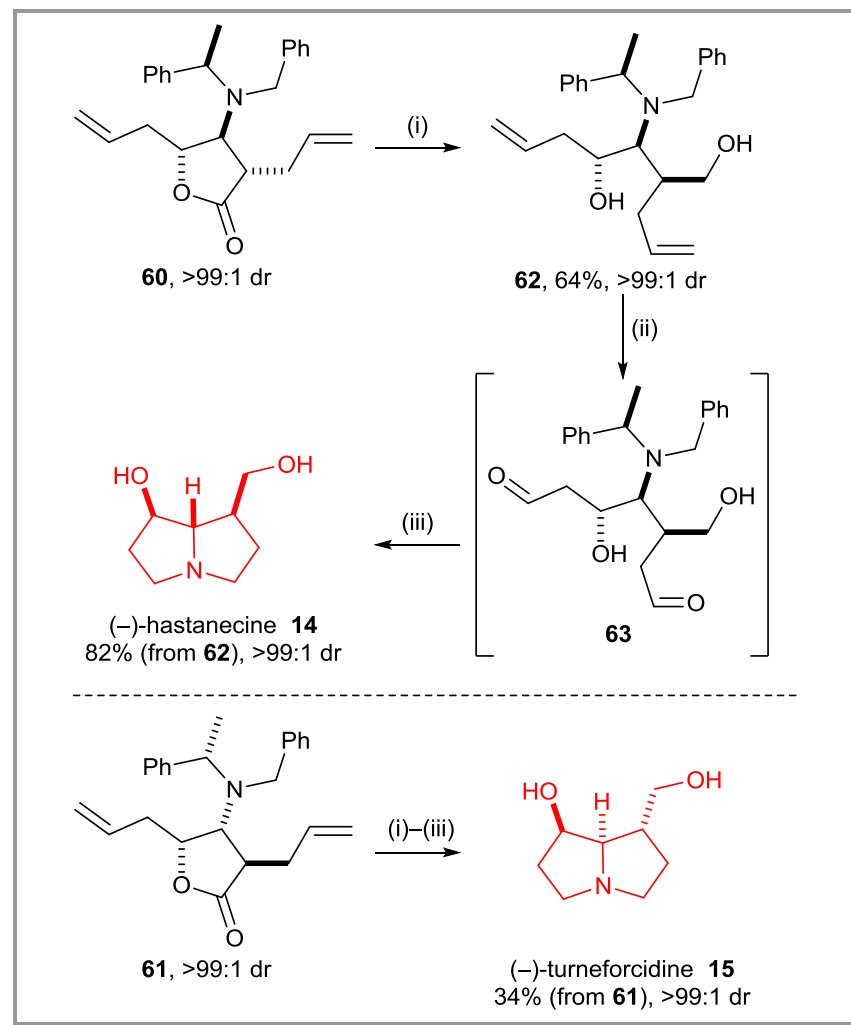

Scheme 5 Reagents and Conditions: (i) $\mathrm{LiAlH}_{4}, \mathrm{THF}, 0{ }^{\circ} \mathrm{C}, 2 \mathrm{~h}$; (ii) $\mathrm{HCl}(2.0 \mathrm{M}$ in $\mathrm{Et}_{2} \mathrm{O}$ ) then $\mathrm{O}_{3}, \mathrm{CH}_{2} \mathrm{Cl}_{2} / \mathrm{MeOH}(1: 1),-78{ }^{\circ} \mathrm{C}$ then polymer-bound $\mathrm{PPh}_{3}, \mathrm{rt}, 2$ h; (iii) $\mathrm{H}_{2}$ (5 atm), $\mathrm{Pd}(\mathrm{OH})_{2} / \mathrm{C}, \mathrm{MeOH} / \mathrm{AcOH}(10: 1), \mathrm{rt}, 48 \mathrm{~h}$ then $50{ }^{\circ} \mathrm{C}, 72 \mathrm{~h}$.

Allylation of the lithium $\beta$-amino enolate derived from deprotonation of $\beta$-amino ester $\mathbf{5 8}$ with LDA gave $\mathbf{6 4}$ in 93\% yield and 96:4 dr. ${ }^{36}$ Ring-closing metathesis of $\mathbf{6 4}$ in the presence of Grubbs I catalyst followed by 0 -TES deprotection with HF-pyridine gave $\mathbf{6 5}$ in $93 \%$ yield and $>99: 1 \mathrm{dr}$. Subsequent reduction of $\mathbf{6 5}$ with $\mathrm{LiAlH}_{4}$ gave diol $\mathbf{6 6}$ in 95\% yield and >99:1 dr. Ozonolysis of the corresponding hydrochloride salt $\mathbf{6 6} \cdot \mathrm{HCl}$ followed by hydrogenolysis/double reductive cyclisation of the corresponding dialdehyde $\mathbf{6 7}$ gave (-)-platynecine $16\left\{[\alpha]_{D^{20}}-58.8\right.$ (c 0.9 in EtOH) $\}$ in $51 \%$ yield (from 66) and >99:1 dr (Scheme 6).

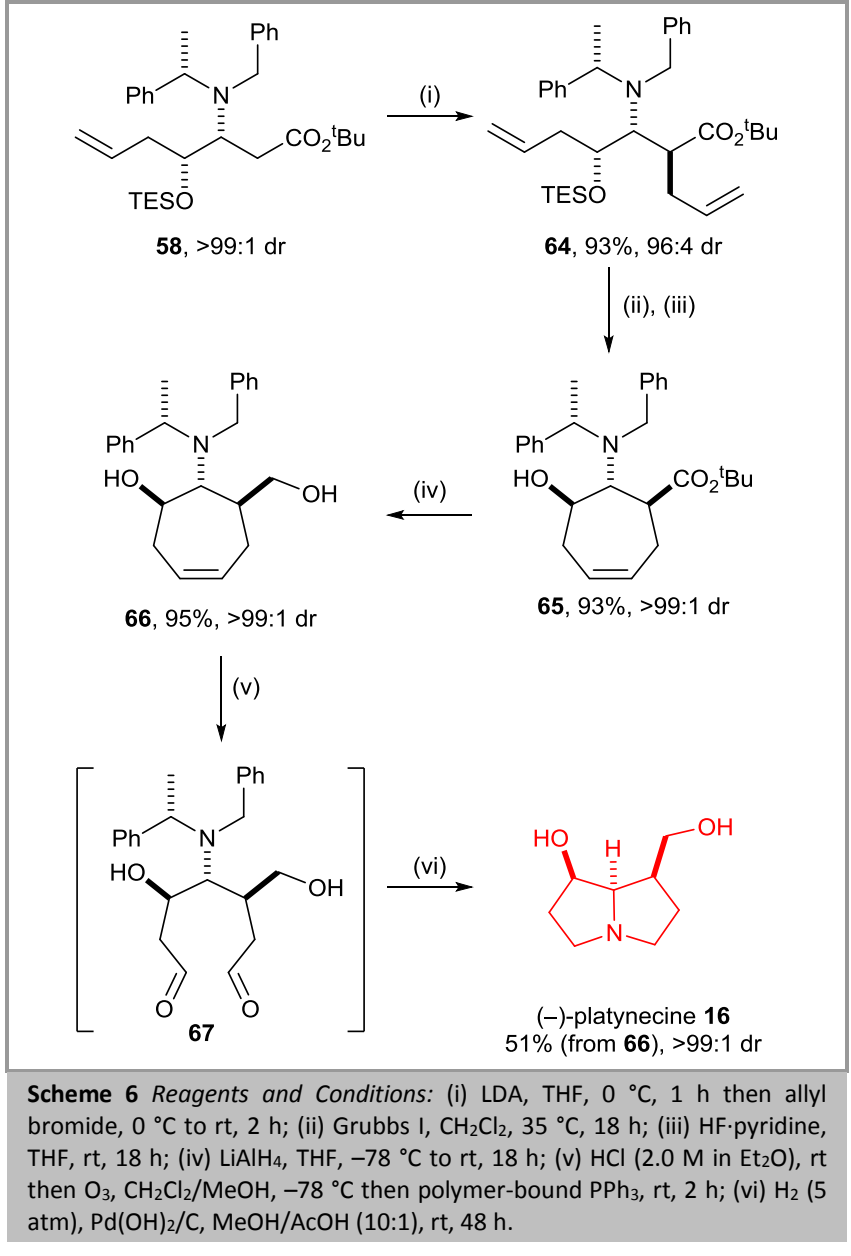

5. Asymmetric syntheses of (-)-macronecine, (-)petasinecine, (-)-1-epi-macronecine, (+)-1-epipetasinecine and $(+)$-2-epi-rosmarinecine

This double reductive cyclisation approach has also been employed in the synthesis of 1-hydroxymethyl-2-hydroxy substituted pyrrolizidines. Conjugate addition of $(S)-21$ to $\alpha, \beta$ unsaturated ester $\mathbf{2 6}$ followed by reaction with acrolein, either following a one-pot or stepwise approach, ${ }^{37}$ introduces the extra hydroxyl group at the $\mathrm{C}(2)$-position of the pyrrolzidine scaffold. Reaction of a diastereoisomerically pure enolate [either derived from conjugate addition of (S)-21 to $\alpha, \beta$ unsaturated ester 26, or from deprotonation of $\beta$-amino ester 70] with acrolein creates two further stereogenic centres, and therefore four diasteroisomeric products are possible. By tuning the reaction conditions, we have managed to produce all four possible diastereomeric products 71-74 in moderate yields. For example, conjugate addition of $(S)-21$ to $\alpha, \beta$ unsaturated ester $\mathbf{2 6}$ followed by addition of acrolein to the corresponding lithium (Z)- $\beta$-amino enolate (Z)-69 gave a 12:7:28:53 mixture of $\mathbf{7 1}, \mathbf{7 2}, \mathbf{7 3}$ and $\mathbf{7 4}$, respectively, from which 74 was isolated in $41 \%$ yield and $>99: 1 \mathrm{dr}$. The alternative 'stepwise' protocol, whereby deprotonation of $\beta$ amino ester $\mathbf{7 0}$ with lithium 2,2,6,6-tetramethylpiperidine (LiTMP) followed by reaction of the resultant lithium $(E)-\beta$ amino enolate ${ }^{28}(E)-68$ with acrolein gave a 5:1:72:22 mixture of 71, 72, 73 and 74, respectively, from which $\mathbf{7 3}$ was isolated in $49 \%$ yield and $>99: 1 \mathrm{dr}$. The optimised conditions for the isolation of $\mathbf{7 1}$ involved transmetallation of the corresponding lithium (Z)- $\beta$-amino enolate $(Z)-69$ [which was derived from 
conjugate addition of $(S)$-21 to $\alpha, \beta$-unsaturated ester 26] upon addition of $\mathrm{TiCl}(\mathrm{O} \mathrm{Pr})_{3}$, followed by treatment with acrolein, which gave a 49:15:23:13 mixture of 71, 72, 73 and 74, respectively, from which $\mathbf{7 1}$ was isolated in $22 \%$ yield and $>99: 1 \mathrm{dr}$. The optimised conditions for the formation of $\mathbf{7 2}$ involved treatment of lithium $(E)$ - $\beta$-amino enolate $(E)$-68 (which was generated upon deprotonation of $\beta$-amino ester $\mathbf{7 0}$ with $\mathrm{LDA}$ ) with $\mathrm{B}(\mathrm{OMe})_{3}$, followed by the addition of acrolein to give a 10:33:31:26 mixture of $\mathbf{7 1}, \mathbf{7 2}, \mathbf{7 3}$ and $\mathbf{7 4}$, respectively, from which $\mathbf{7 2}$ was isolated as a single diastereoisomer ( $>99: 1 \mathrm{dr}$ ) in 14\% yield (Scheme 7).

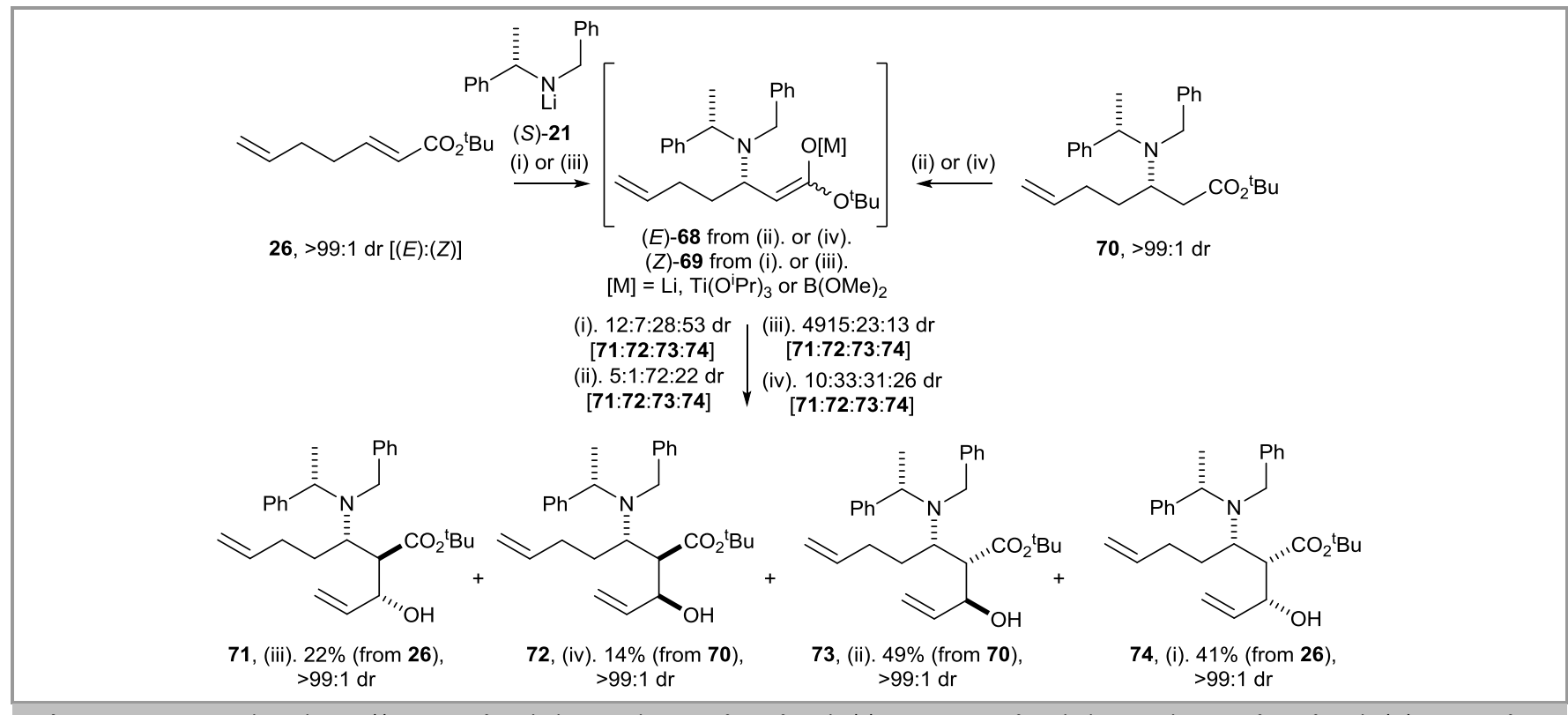

Scheme 7 Reagents and Conditions: (i) THF, $-78^{\circ} \mathrm{C}, 2 \mathrm{~h}$ then acrolein, $-78^{\circ}$ to $0{ }^{\circ} \mathrm{C}, 3 \mathrm{~h}$; (ii) LiTMP, THF, $0{ }^{\circ} \mathrm{C}, 1 \mathrm{~h}$ then acrolein, $-78^{\circ}$ to $0{ }^{\circ} \mathrm{C}, 3 \mathrm{~h}$; (iii) THF, $-78{ }^{\circ} \mathrm{C}, 2$ $\mathrm{h}$ then $\mathrm{TiCl}(\mathrm{O} \mathrm{Pr})_{3},-78{ }^{\circ} \mathrm{C}, 1 \mathrm{~h}$ then acrolein, -78 to $0{ }^{\circ} \mathrm{C}, 3 \mathrm{~h}$; (iv) LDA, THF, $0{ }^{\circ} \mathrm{C}, 2 \mathrm{~h}$ then $\left.\mathrm{B}(\mathrm{OMe})\right)_{3},-78{ }^{\circ} \mathrm{C}$, $1 \mathrm{~h}$ then acrolein, -78 to $0{ }^{\circ} \mathrm{C}, 3 \mathrm{~h}$.

Reduction of $\beta$-amino ester $\mathbf{7 1}$ with $\mathrm{LiAlH}_{4}$ gave aminodiol $\mathbf{7 5}$ in $70 \%$ yield and $>99: 1 \mathrm{dr}$. Treatment of $75 \cdot \mathrm{HCl}$ with $\mathrm{O}_{3}$ followed by the addition of polymer supported $\mathrm{PPh}_{3}$ gave the corresponding dialdehyde 76, and subsequent hydrogenolytic removal of the $\mathrm{N}$-protecting groups facilitated in situ double reductive cyclisation to give $(-)-1$-epi-macronecine $77\left\{[\alpha]_{\mathrm{D}}{ }^{20}\right.$ -96.0 (c 0.1 in EtOH) $\}$ in 69\% isolated yield (from 75) and $>99: 1 \mathrm{dr}$ after purification (Scheme 8).

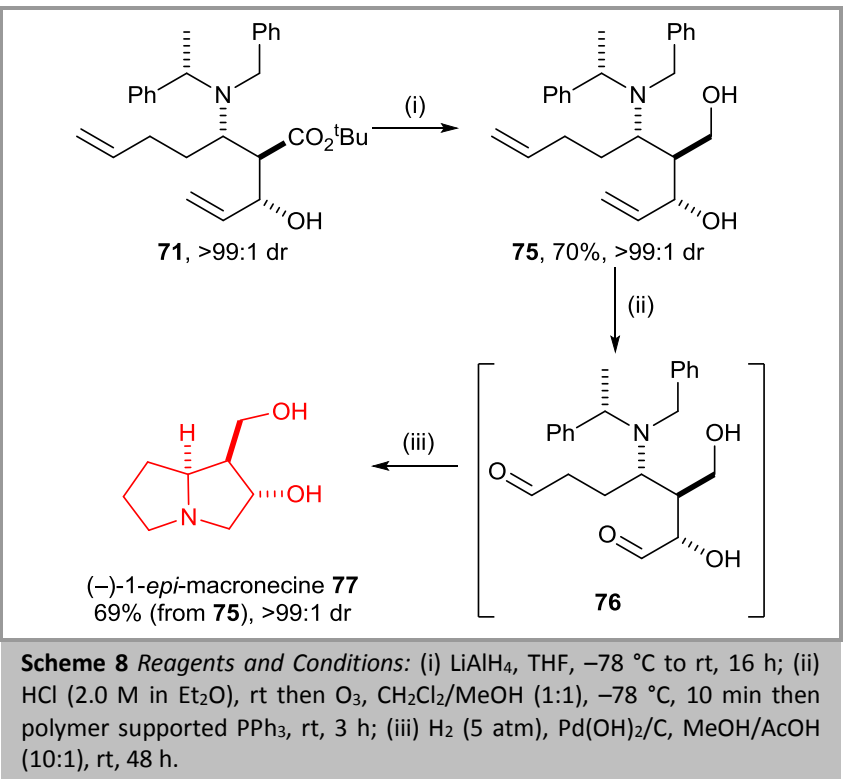

This three step protocol was also applied to $\beta$-amino esters 72-74, which gave, after purification on DOWEX ion exchange resin, (-)-petasinecine $17\left\{[\alpha]_{\mathrm{D}^{20}}-26.0(c 0.8 \mathrm{in} \mathrm{EtOH})\right\},(+)-1$ epi-petasinecine $78\left\{[\alpha]_{\mathrm{D}}{ }^{20}+30.0(c 0.8\right.$ in EtOH $\left.)\right\}$, and $(-)$ macronecine $18\left\{[\alpha]_{\mathrm{D}} 20-40.0(c 0.6\right.$ in EtOH $\left.)\right\}$, respectively, as a single diasteroisomer (>99:1 dr) in $47-56 \%$ yield over 3 steps (Scheme 9).

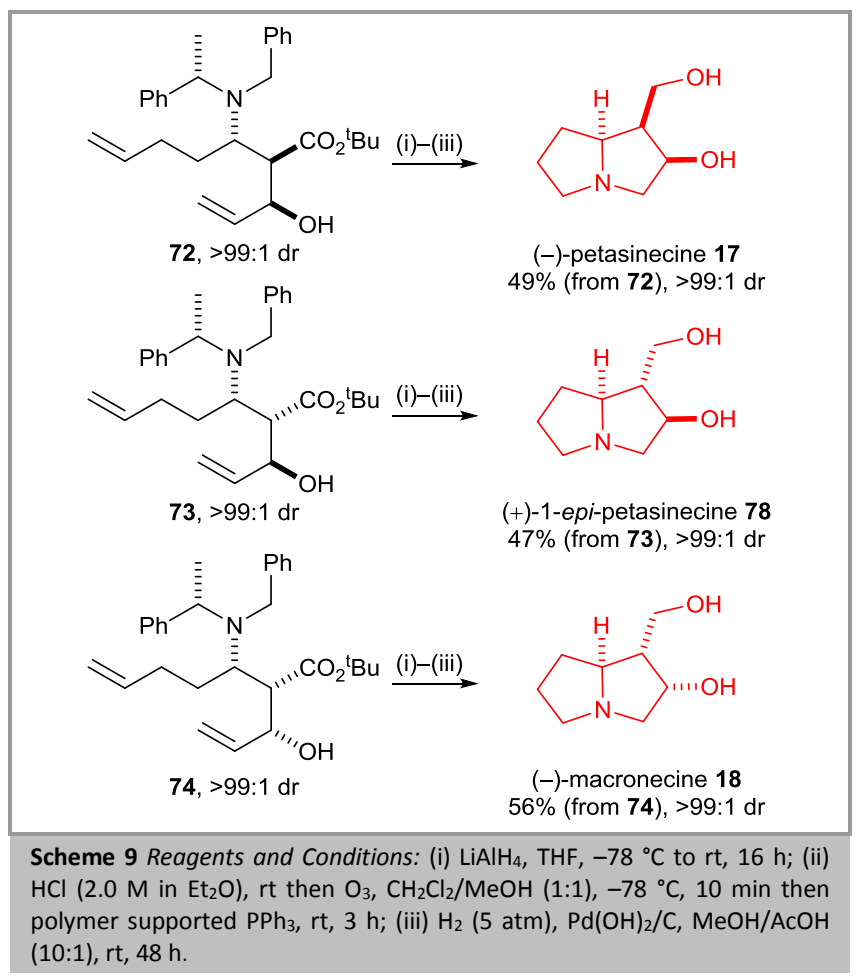


Finally, the more densely hydroxylated pyrrolzidine (+)-2-epirosmarinecine $\mathbf{8 1}$ was prepared from enantiopure $\gamma$-silyloxy- $\beta$ amino ester 58. Treatment of $\mathbf{5 8}$ with LiTMP followed by the addition of acrolein gave only one diastereoisomeric product in this case. Chromatographic purification of the crude reaction mixture afforded 79 in 96\% yield and >99:1 dr. Hydrolysis of 79 under acidic conditions gave the corresponding carboxylic acid, which was sequentially treated with $\mathrm{LiAlH}_{4}$ and $\mathrm{HF}$ in pyridine to give triol $\mathbf{8 0}$ in 76\% yield (from 79) and $>99: 1 \mathrm{dr}$. Ozonolysis of $\mathbf{8 0} \cdot \mathrm{HCl}$ followed by hydrogenolytic $\mathrm{N}$ deprotection and in situ double reductive cyclisation gave 81·HOAc which was isolated in $65 \%$ yield and $>99: 1 \mathrm{dr}$. In order to facilitate the purification of $(+)$-2-epi-rosmarinecine 81, the crude sample of 81·HOAc was first treated with $\mathrm{Ac}_{2} \mathrm{O}$ in pyridine to give $\mathbf{8 2}$ in $77 \%$ isolated yield, and subsequent global deprotection of all three acetyl groups within $\mathbf{8 2}$ upon treatment with $\mathrm{K}_{2} \mathrm{CO}_{3}$ in $\mathrm{MeOH}$ gave (+)-2-epi-rosmarinecine $81\left\{[\alpha]_{D^{20}}+18.3(c 0.37\right.$ in EtOH $\left.)\right\}$ in quantitative yield and $>99: 1 \mathrm{dr}$ (Scheme 10).

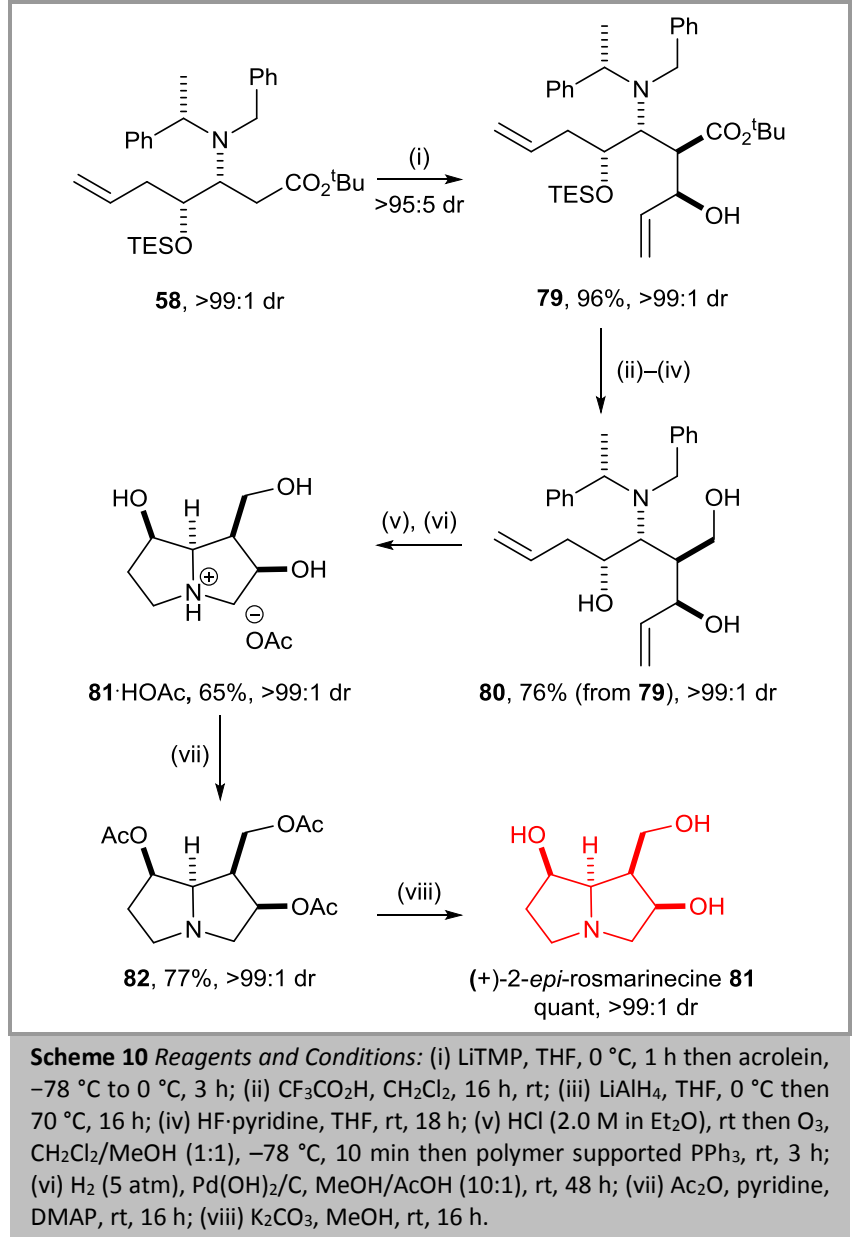

\section{Conclusion}

In conclusion, a protocol for the double reductive cyclisation of enantiopure amines bearing two pendant aldehyde functionalities proved to be an efficient and general method for the rapid construction of pyrrolizines, indolizidines and quinolizidines, including polyhydroxylated analogues. The key cyclisation precursors $\mathbf{8 5}$ were prepared via the diastereoselective conjugate addition of the requisite antipode of enantiopure lithium amide reagent 21 to either an $\alpha, \beta$ unsaturated ester $\mathbf{8 3}(\mathrm{n}=1$ or $2, \mathrm{X}=\mathrm{H}$ or TES) or an $\alpha$-alkenyl $\alpha, \beta$-unsaturated ester $84(\mathrm{n}=1$ or $2, \mathrm{~m}=1$ or 2 ) as the stereodefining step. Following oxidative cleavage of the olefinic units, the double reductive cyclisation was achieved in a single operation upon hydrogenoylsis of the $\mathrm{N}$-benzyl groups followed by in situ cyclisation and hydrogenation to form both rings within the pyrrolizidine, indolizidine or quinolizidine target scaffolds. This protocol was successfully applied in the asymmetric syntheses of 13 naturally occurring azabicyclic alkaloids and their analogues in good yield (Figure 4). 


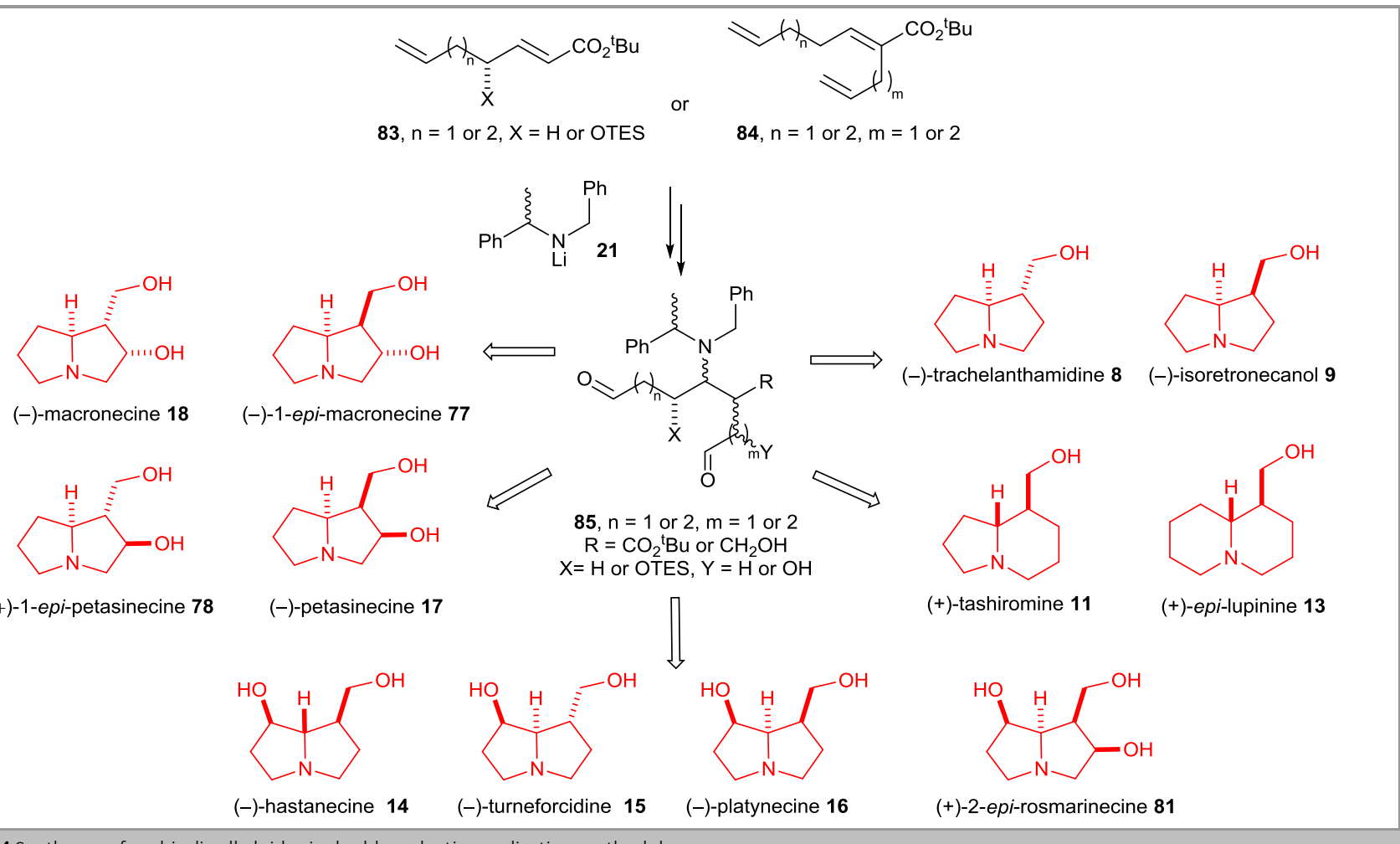

Figure 4 Syntheses of azabicylic alkaloids via double reductive cyclisation methodology.

\section{References}

(1) Usaki, H.; Toyo-oka, M.; Kanzaki, H.; Okuda, T.; Nitoda, T. Bioorg. Med. Chem. 2009, 17, 7248.

(2) Hu, X.-G.; Bartholomew, B.; Nash, R. J.; Wilson, F. X.; Fleet, G. W. J.; Nakagawa, S.; Kato, A.; Jia, Y.-M.; van Well, R.; Yu, C.-Y. Org. Lett. 2010, 12, 2562.

(3) Colegate, S. M.; Dorling, P. R.; Huxtable, C. R. Aust. J. Chem. 1979 $32,2257$.

(4) Dorling, P. R.; Colegate, S. M.; Huxtable, C. R. Toxicon 1983, 21, 93.

(5) Fitch, R. W.; Garraffo, H. M.; Spande, T. F.; Yeh, H. J. C.; Daly, J. W. J. Nat. Prod. 2003, 66, 1345.

(6) Tranchelanthamidine was originally named tranchelantamidine; see: Men'shikov, G. P.; Borodina, G. M. Zh. Obshch. Khim. 1945, 15, 225.

(7) Galinovsky, F.; Goldberger, H.; Pohm, M. Monatsh. Chem. 1949, 80, 550.

(8) Men'shikov, G. P.; Kuzovkov, A. D. Zh. Obshch. Khim. 1949, 19, 1702.

(9) Labenskii, A. S.; Men'shikov, G. P. Zh. Obshch. Khim. 1948, 18 1836.

(10) For example, see: Belakhdar, G.; Benjouad, A.; Kessabi, M.; Abdennebi, E. H. J. Mater. Environ. Sci. 2014, 3, 811.

(11) Pomeroy, A. R.; Paper, C. Eur. J. Pharm. 1971, 14, 374.

(12) Hoang, L. S.; Tran, M. H.; Lee, J. S.; To, D. C.; Nguyen, V. T.; Kim, J. A.; Lee, J. H.; Woo, M. H.; Min, B. S. Chem. Pharm. Bull. 2015, 63, 481.

(13) Ohimiya, S.; Kubo, H.; Otomasu, H.; Saito, K.; Murakoshi, I. Heterocycles 1990, 30, 537.

(14) Sadykov, A.; Lazur'eveskii, G Zh. Obshch. Khim. 1943, 13, 319.

(15) (a) Winterfeld, K.; Holschneider, F. W. Chem. Ber. 1931, 64, 137. (b) Beck, A. B.; Goldspink, B. H.; Knox, J. R. J. Nat. Prod. 1979, 42, 385.

(16) For a review, see: Brambilla, M.; Davies, S. G.; Fletcher, A. M.; Thomson, J. E. Tetrahedron: Asymmetry 2014, 25, 387.

(17) Konovalov, V. S.; Men'shikov, G. P. Zh. Obshch. Khim. 1945, 15, 328.
(18) Men'shikov, G. P.; Denisova, S. O.; Massagetov, P. S. Zh. Obshch. Khim. 1952, 22, 1465.

(19) For example, see: (a) Konovalova, R. A.; Orekhov, A. P. Bull. Soc. Chim. Fr. 1937, 4, 2037. (b) Culvenor, C. C. J.; Kobetskaya, N. O.; Smith, L. W.; Utkin, L. M. Aust. J. Chem. 1968, 21, 1671. (c) Asada, Y.; Furuya, T. Chem. Pharm. Bull. 1984, 32, 475.

(20) Yamada, K.; Tatematsu, H.; Unno, R.; Hirata, Y. Tetrahedron Lett. 1978, 46, 4543. (b) Haberer, W.; Dobler, S. Chemoecology 1999, 9, 169.

(21) Danilova, A.; Utkin, L.; Massagetov, P. Zh. Obshch. Khim. 1955, 25, 831.

(22) De Waal, H. L. Nature 1940, 140, 777.

(23) We have recently reported asymmetric syntheses of azabicyclic targets via stepwise ring-forming protocols; see: (a) Davies, S. G.; Fletcher, A. M.; Foster, E. M.; Houlsby, I. T. T.; Roberts, P. M.; Schofield, T. M.; Thomson, J. E. Chem. Commun. 2014, 50, 8309. (b) Davies, S. G.; Fletcher, A. M.; Foster, E. M.; Houlsby, I. T. T.; Roberts, P. M.; Schofield, T. M.; Thomson, J. E. Org. Biomol. Chem. 2014, 12, 9223. (c) Davies, S. G.; Fletcher, A. M.; Hughes, D. G.; Lee, J. A.; Price, P. D.; Roberts, P. M.; Russell, A. J.; Smith, A. D.; Thomson, J. E.; Williams, O. M. H. Tetrahedron 2011, 67, 9975. (d) Davies, S. G.; Hughes, D. G.; Lee, J. A.; Price, P. D.; Roberts, P. M.; Russell, A. J.; Smith, A. D.; Thomson, J. E.; Williams, O. M. H. Synlett 2010, 567.

(24) For representative examples, see: (a) Cutter, A. C.; Miller, I. R.; Keily, J. F.; Bellingham, R. K.; Light, M. E.; Brown, R. C. D. Org. Lett. 2011, 13, 3988. (b) Janowitz, A.; Vavrecka, M.; Hesse, M. Helv. Chim. Acta 1991, 74, 1352. (c) Vavrecka, M.; Jonawitz, A.; Hesse, M. Tetrahedron Lett. 1991, 32, 5543. (d) O'Connell, K. M.; DiazGavilan, M.; Galloway, W. R. J. D.; Spring, D. R. Beilstein J. Org. Chem. 2012, 8, 850. (e) Airiau, E.; Spangenberg, T.; Girard, N.; Breit, B.; Mann, A. Org. Lett. 2010, 12, 528. (f) Gradnig, G.; Grassberger, B. V.; Stütz, A. E. Tetrahedron Lett. 1991, 32, 4889. (g) Kiss, L.; Forró, E.; Fülöp, F. Beilstein J. Org. Chem. 2015, 11, 596. (h) Barthelme, A.; Richards, D.; Mellor, I. R.; Stockman, R. A. Chem. Commun. 2013, 49, 10507. (i) Jones, T. H.; Highet, R. J.; Don, A. W.; Blum, M. S. J. Org. Chem. 1986, 51, 2712. (j) Amorde, S. M.; Jewett, I. T.; Martin, S. F. Tetrahedron 2009, 65, 3222. 
(25) We have previously reported the asymmetric synthesis of some 3,4-dihydroxyhomoprolines from the corresponding D-pentoses using $\mathrm{N}$-debenzylation followed by in situ reductive cyclisation to form the pyrrolidine scaffold; see: Davies, S. G.; Foster, E. M.; Lee, J. A.; Roberts, P. M.; Thomson, J. E. Tetrahedron 2013, 69, 8680.

(26) For reviews, see: (a) Davies, S. G.; Smith, A. D.; Price, P. D. Tetrahedron: Asymmetry 2005, 16, 2833. (b) Davies, S. G.; Fletcher, A. M.; Roberts, P. M.; Thomson, J. E. Tetrahedron: Asymmetry 2012, 23, 1111.

(27) Brambilla, M.; Davies, S. G.; Fletcher, A. M.; Roberts, P. M.; Thomson, J. E. Tetrahedron 2014, 70, 204.

(28) (a) Davies, S. G.; Walters, I. A. S. J. Chem. Soc., Perkin Trans. 1 1994, 1129. (b) Davies, S. G.; Foster, E. M.; McIntosh, C. R.; Roberts, P. M.; Rosser, T. E.; Smith, A. D.; Thomson, J. E. Tetrahedron: Asymmetry 2011, 22, 1035.

(29) (a) Aciro, C.; Claridge, T. D. W.; Davies, S. G.; Roberts, P. M.; Russell, A. J.; Thomson, J. E. Org. Biomol. Chem. 2008, 6, 3751. (b) Aciro, C.; Davies, S. G.; Roberts, P. M.; Russell, A. J.; Smith, A. D.; Thomson, J. E. Org. Biomol. Chem. 2008, 6, 3762. (c) Bond, C. W.; Cresswell, A. J.; Davies, S. G.; Kurosawa, W.; Lee, J. A.; Fletcher, A. M.; Roberts, P. M.; Russell, A. J.; Smith, A. D.; Thomson, J. E. J. Org. Chem. 2009, 74, 6735. (d) Brennan, M. B.; Claridge, T. D. W.; Compton, R. G.; Davies, S. G.; Fletcher, A. M.; Henstridge, M. C.; Hewings, D. S.; Kurosawa, W.; Lee, J. A.; Roberts, P. M.; Schoonen, A. K.; Thomson, J. E. J. Org. Chem. 2012, 77, 7241. (e) Brennan, M.
B.; Davies, S. G.; Fletcher, A. M.; Lee, J. A.; Roberts, P. M.; Russell, A J.; Thomson, J. E. Aust. J. Chem. 2015, 68, 610. (f) Brennan, M.; Csatayová, K.; Davies, S. G.; Fletcher, A. M.; Green, W. D.; Lee, J. A.; Roberts, P. M.; Russell, A. J.; Thomson, J. E. J. Org. Chem. 2015, 80, 6609.

(30) Brambilla, M.; Davies, S. G.; Fletcher, A. M.; Roberts, P. M.; Thomson, J. E. Tetrahedron 2016, 72, 7417.

(31) Claridge, T. D. W.; Davies, S. G.; Lee, J. A.; Nicholson, R. L.; Roberts, P. M.; Russell, A. J.; Smith, A. D.; Toms, S. M. Org. Lett. 2008, 10, 5437.

(32) Davies, S. G.; Ichihara, O.; Walters, I. A. S. J. Chem. Soc., Perkin Trans. 1 1994, 1141.

(33) Wensheng, Y.; Mei, Y.; Kang, Y.; Hua, Z.; Jin, Z. Org. Lett. 2004, 6, 3217.

(34) Brambilla, M.; Davies, S. G.; Fletcher, A. M.; Roberts, P. M.; Thomson, J. E. Tetrahedron 2016, 72, 4523.

(35) (a) Keck, G. E.; Tarbet, K. H.; Geraci, L. S. J. Am. Chem. Soc. 1993, 115, 8467. (b) Keck, G. E.; Welch, D. S.; Vivian, P. K. Org. Lett. 2006, 8, 3667. (c) Stambouli, A.; Amouroux, M.; Chastrette, M. Tetrahedron Lett. 1987, 28, 5301.

(36) The analogous treatment of $\beta$-amino ester $\mathbf{5 7}$ with LDA followed by allyl bromide gave only returned $\mathbf{5 7}$.

(37) Brambilla, M.; Davies, S. G.; Fletcher, A. M.; Roberts, P. M.; Thomson, J. E. Tetrahedron 2016, 72, 7449.

\section{Biosketches}

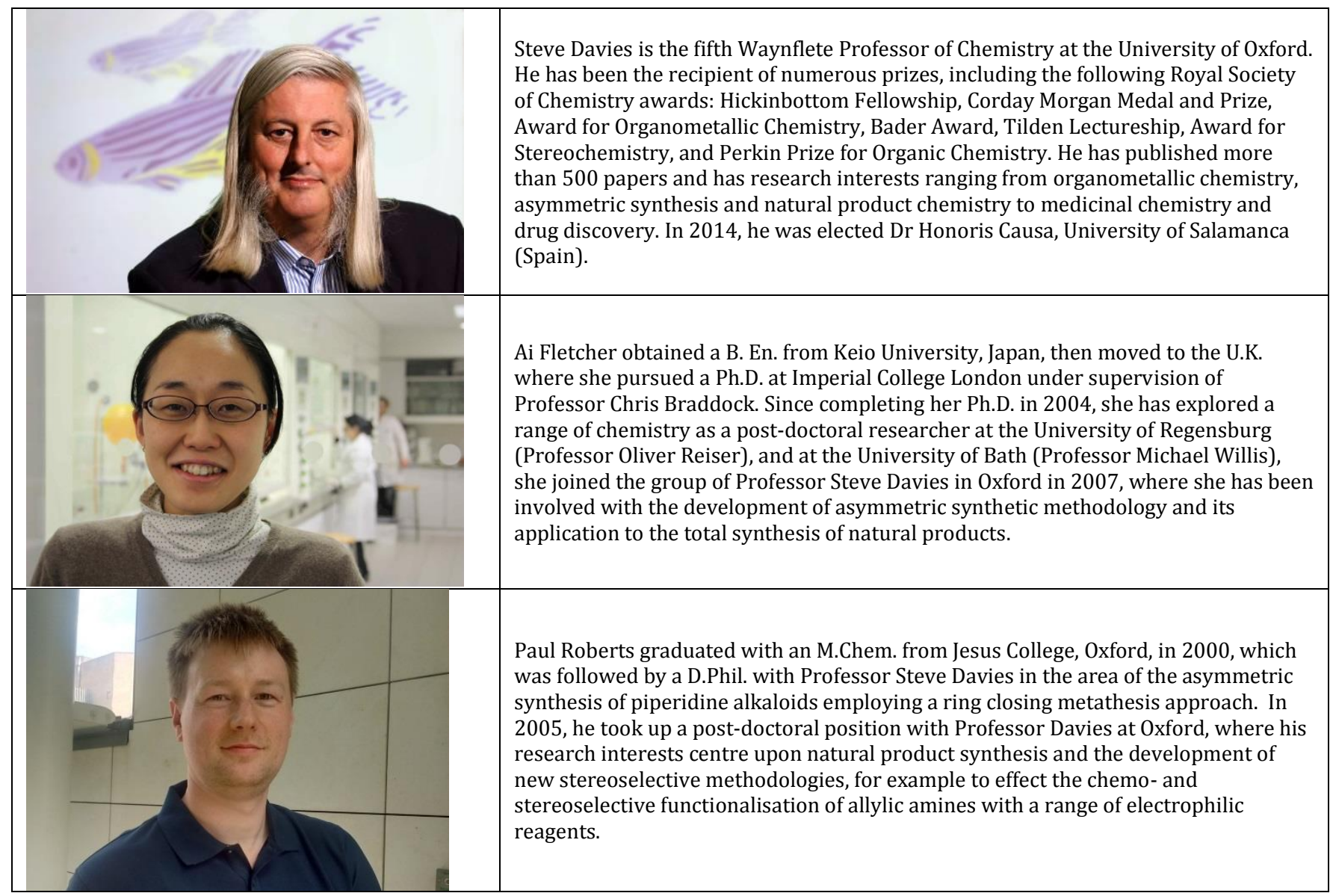




Jim Thomson studied chemistry at the University of Oxford where he gained an
M.Chem. (2003) and then D.Phil. (2007), working with Professor Steve Davies in the
area of $\beta$-amino acid organocatalysis. He then took up a post-doctoral position with
Professor Davies, as a Junior Research Fellow, and in 2010 was appointed to a
Research Fellowship in association with St. Catherine's College, Oxford. His research
interests centre upon the development of novel asymmetric transformations and the
total synthesis of natural products.

